\title{
Intake, digestibility and nitrogen use efficiency in crossbred F1 Holstein $x$ Zebu grazing cows ${ }^{1}$
}

\section{Stefanie Alvarenga Santos ${ }^{2}$, Sebastião de Campos Valadares Filho ${ }^{2}$, Edenio Detmann², Rilene Ferreira Diniz Valadares ${ }^{3}$, José Reinaldo Mendes Ruas ${ }^{4}$, Laura Franco Prados ${ }^{2}$, Paloma de Melo Amaral ${ }^{2}$, Lays Débora Silva Mariz ${ }^{2}$}

\footnotetext{
1 Projeto de pesquisa financiado pela FAPEMIG e pelo INCT de Ciência Animal.

2 Departamento de Zootecnia, Universidade Federal de Viçosa, 36570-000, Viçosa, MG.

${ }^{3}$ Departamento de Medicina Veterinária, Universidade Federal de Viçosa, 36570-000, Viçosa, MG.

${ }^{4}$ Empresa de Pesquisa Agropecuária de Minas Gerais - EPAMIG, 35794-000, Felixlândia, MG.
}

ABSTRACT - The objective of this study was to evaluate intake, digestibility and nitrogen (N) compounds use efficiency in F1 Holstein $\times$ Zebu grazing cows. Eighteen crossbred cows (six Holstein $\times$ Gir, six Holstein $\times$ Guzerat, and six Holstein $\times$ Nellore) were used in the experiment, constituting three experimental treatments in simple random samples, under the same feeding conditions. At the estimation of individual intake at grazing, titanium dioxide was used for estimating fecal excretion and indigestible neutral detergent fiber, in order to determine pasture intake. There was effect of the lactation period on nutrient intake, except for the intakes of dry matter (DM), organic matter (OM) and total digestible nutrients (TDN) in \% of body weight (BW), as well as those of non-fibrous carbohydrates (NFC), in kg. The digestibility coefficients of crude protein (CP), neutral detergent fiber corrected for ash and protein (NDFap) and the contents of TDN varied in function of the lactation period, whereas the coefficients of digestibility of DM, ether extract (EE) and OM did not present such effect. The total milk production projected at 305 days of lactation for Holstein $\times$ Gir cows was superior in relation to Holstein $\times$ Guzerat and Holstein $\times$ Nellore cows. The excretion of urea into urine and of urea $\mathrm{N}$ into the milk and the plasma presented quadratic behavior in function of the lactation period. The utilization of the genetic group from Holstein $\times$ Zebu grazing cows does not cause alterations in intake, nutrient digestibility or nitrogen use efficiency; however, there is variation in function of the lactation period. Holstein $\times$ Gir cows presented greater accumulated production during lactation and persistence, followed by Holstein $\times$ Guzerat and Holstein $\times$ Nellore cows.

Key Words: Brachiaria decumbens, crossbreeding, milk production, performance

\section{Introduction}

Crossbred cows, because of their own features and rusticity, permit certain flexibility in terms of milk production. In general, farmers choose alternative production systems which privilege tropical pasture as animal staples in the summer and roughage provided in the troughs during the winter, when there is shortage of rain and luminosity. These systems, when compared with more intensive ones, may present more competitive economical results, once animal feeding has a significant part in the costs of milk production. Among the several components in cattle diets, the pasture is that which presents lowest cost per nutrient unit.

However, information on the variation of crossbred cows performance during lactation, especially grazing, is still scarce in our literature. Many pieces of information are found in the international literature. Nevertheless, in general, such information is more often about dairy cattle of predominantly Holstein blood, which are not very adapted to semi-intensive systems. For so, it is necessary that study on the performance of crossbred cows throughout their lactation periods, undergoing different feeding plans, especially grazing during the summer be carried out. Still, information concerning behavior of intake and milk production throughout the whole lactation period is necessary, for during this period there is variation in the nutritional requirements according to the productive and reproductive stages of life. Thus, the objective of this study was to evaluate intake, digestibility and nitrogen use efficiency in F1 Holstein $\times$ Zebu grazing cows.

\section{Material and Methods}

This experiment was conducted at Research Farm of the EPAMIG (Empresa de Pesquisa Agropecuária de Minas Gerais), from January, 2008 to May, 2008. The chemicalbromatological analyses were carried out at the laboratory of ruminant nutrition at UFV (Universidade Federal de 
Viçosa). The procedures of handling and humanitarian handling of animals followed the guidelines of Universidade Federal de Viçosa.

Eighteen F1 (six Holstein $\times$ Gir, six Holstein $\times$ Guzerat, and six Holstein $\times$ Nellore) recently-calved cows, constituting three experimental periods were distributed in simple randomized samples under the same feeding conditions with pasture overconcentrated with $22 \%$ crude protein (CP). Cows were milked mechanically at $7 \mathrm{~h} 00$ and $14 \mathrm{~h} 00$, and milk control was performed weekly.

Every day after milking, cows were led to Brachiaria decumbens paddocks under rotational stocking, provided with troughs with mineral salt and water ad libitum. Data relative to the estimates of intake and digestibility of the dry matter were obtained during 6 experimental periods of 21 days, which started from the first lactation week. The data concerning milk production were collected until the end of the lactation period of cows.

For estimation of individual pasture intake, two indicators were used, so that there were six 21-day experimental periods: 14 days for adaptation and seven for collections. Titanium dioxide was used to estimate fecal excretion. From the seventh to the eighteenth day, $15 \mathrm{~g}$ of this indicator were supplied orally on a single dose, after milking (15h00), for each cow, by means of probe, totalizing 11 days of application: six days for stabilization of the indicator excretion in the feces, and five for feces collections, which were performed twice weekly after milking sessions.

After dried and ground, the fecal samples obtained were composed proportionally, based on dry weight in air, per animal, and then submitted to administration of titanium dioxide content, following the technique described by Myers et al. (2004). Fecal excretion was obtained by dividing the titanium dioxide intake by its concentration in feces.

For determination of individual forage consumption, indigestible acid detergent fiber (iADF) was utilized as internal marker. The iADF consumed through the pasture was estimated by means of the esophageal extrusa, collected on the sixteenth day of each experimental period by utilizing two crossbred steers fistulated in the esophagus. For quantification of iADF in the feces samples, concentrate and extrusa, these were put in Ankon bags (F57-filter bags) and incubated in the rumen of a crossbred fistulated animal for a 264-hour period (Casali et al., 2008). The remaining material from the incubation was previously washed with water and then submitted to extraction with acid detergent, and the residue was considered the iADF. Estimates of individual dry matter intake (DMI) were obtained through the following expression: DMI $(\mathrm{kg} / \mathrm{day})=[(($ fecal excretion * concentration of iADF in the feces) - iADF in the
concentrate)/iADF concentration in the extrusa] + dry matter intake of concentrate.

The total concentrate (Table 1) was supplied in the individual milking trough and was calculated according to the milk production, with $1 \mathrm{~kg}$ concentrate supplied for every $3 \mathrm{~kg}$ milk produced; $8 \mathrm{~kg}$ of milk was the initial production for the grant of the first kg of concentrate. After milking, leftovers from every trough were collected and weighed. The concentrate was composed of: soybean meal (24\%), ground corn (68.5\%), urea (2\%), ammonium sulphate (0.2\%), limestone (1.6\%), dicalcium phosphate $(2.3 \%)$, sodium chloride $(0.4 \%)$ and mineral premix $(1 \%)$, with the following composition: cobalt sulphate (7.93\%), copper sulphate (23.9\%), zinc sulphate (63.5\%), potassium iodide (3.17\%) and sodium selenite (1.58\%).

All samples were oven-dried $\left(60^{\circ} \mathrm{C}, 72 \mathrm{~h}\right)$ and processed in knife mill with 2-mm sieve. Samples were stored in plastic bottles for further analyses. Analyses of dry matter (DM), organic matter (OM) and crude protein (CP) were performed as described by the AOAC (1990).

Ether extract (EE) content determination was achieved by Soxhlet extraction with petroleum ether. Neutral detergent fiber corrected for ash and protein (NDFap) and acid detergent fiber corrected for ash and protein (ADFap) were determined by adapted technique of Mertens (2002) and analyzed with addition of thermo-stable alpha-amylase enzyme (Ankon Tech. Corp., Fairport, NY). Lignin was extracted with $72 \%$ sulfuric acid (Van Soest, 1967). Acid detergent insoluble nitrogen (ADIN) was evaluated by the method of Kjeldahl (Licitra et al., 1996).

The non-fibrous carbohydrates corrected for ash and protein (NFCap) were calculated as suggested by Detmann \& Valadares Filho (2010), as follows: NFCap = $100-[(\% \mathrm{CP}-\% \mathrm{CP}$ derived from urea + \%urea $)+\%$ NDFap $+\% \mathrm{EE}+\% \mathrm{ash}]$. The contents of total digestible nutrients (TDN) were calculated according to Weiss (1999), through the following equation: $\mathrm{TDN}(\%)=\mathrm{dCP}+\mathrm{dNDF}+\mathrm{dNFC}+$ $2.25 \mathrm{dEE}$, where $\mathrm{dCP}=$ digestible crude protein; $\mathrm{dNDF}=$ digestible neutral detergent fiber; $\mathrm{dNFC}=$ digestible nonfibrous carbohydrates; and dEE = digestible ether extract.

The collection for estimation of forage mass was performed on the 1st day of the experiment and on the last day of each experimental period, through cutting of 10 areas randomly chosen per paddock and delimited by a $0.7 \times 0.7 \mathrm{~m}$ metallic square. The cut was done near the soil surface, following the technique described by McMeniman (1997), with weighing of every sample to compose the average of forage availability, which was extrapolated per hectare. Next, samples were dried, ground, and composite sample was made for chemical-bromatological composition analyses (Table 1). 
Table 1 - Chemical composition of the pasture samples obtained from esophageal extrusa (EXT) or pasture allowance (PA) used during each experimental period of 21 days, chemical composition of the concentrate, dry matter intake, total digestible nutrient intake and milk production

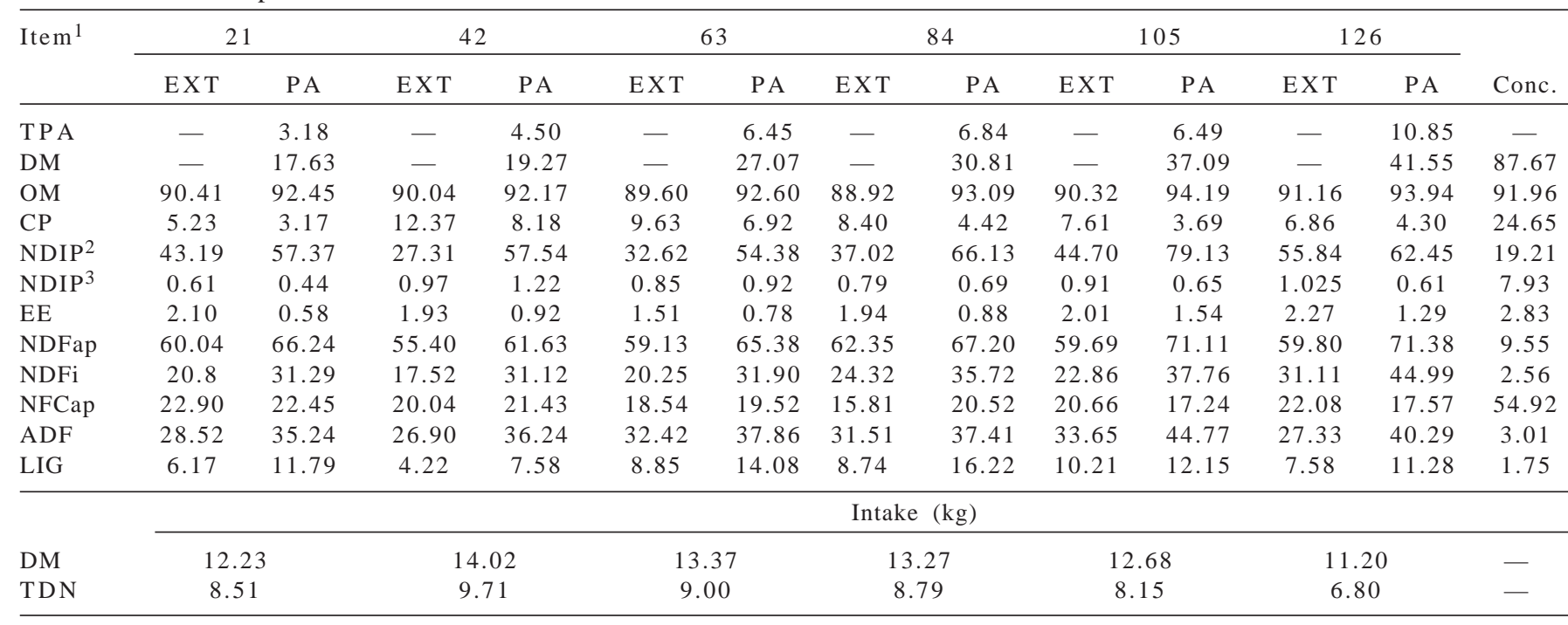

Milk production $(\mathrm{kg})$

$\begin{array}{lcccccccccccc} & 21 & 42 & 63 & 84 & 105 & 126 & 147 & 168 & 189 & 210 & 231 & 252 \\ \text { HGI } & 19.2 & 18.6 & 18.3 & 16.6 & 15.7 & 14.0 & 13.2 & 12.3 & 11.5 & 10.0 & 9.5 & 8.5 \\ \text { HGU } & 18.5 & 18.4 & 16.5 & 15.3 & 14.0 & 13.2 & 11.9 & 12.1 & 10.2 & 9.4 & 8.5 & 7.5 \\ \text { HNE } & 18.3 & 16.5 & 16.3 & 14.7 & 13.5 & 13.1 & 11.6 & 10.5 & 9.0 & 7.7 & 6.6 & 6.5\end{array}$

\footnotetext{
${ }^{1}$ Nutrient on a dry matter basis (g/kg). TPA - total pasture allowance (kg/ha); DM - dry matter; OM - organic matter; CP - crude protein; NDFap - neutral detergent fiber corrected for ash and protein; NDIP - neutral detergent insoluble protein (g/kg NDF); NDFi - indigestible neutral detergent fiber; ADF - acid detergent fiber; LIG lignin; NFCap - non-fiber carbohydrates corrected for ash and protein; EE - ether extract; HGI - Holstein $\times$ Gir; HGU - Holstein $\times$ Guzerat; HNE - Holstein $\times$ Nellore; Conc. - chemical composition of the concentrate.

Blood samples were collected on the $21^{\text {st }}$ day by puncture of the coccygeal vein, with the aid of test-tube containing anticoagulant (EDTA). Immediately, samples were centrifuged at $2800 \mathrm{x}$ g for 15 minutes; plasma samples were then collected and conditioned in glass containers, which were frozen at $-15^{\circ} \mathrm{C}$ for further analyses of plasma urea concentration.

Spot samples of urine were obtained on the $21^{\text {st }}$ day of each experimental period, right after milking, by means of stimulating massage. From the urine collected, after homogenization and filtering, 10 -mL aliquots were obtained and diluted in $40 \mathrm{~mL} 0.036 \mathrm{~N}$ sulfuric acid, according to Valadares et al. (1997). These samples had pH adjusted to value below three in order to avoid bacterial destruction of purine derivatives, and were then frozen for further analyses of urea, total nitrogen, creatinine, uric acid and allantoin. The total daily urinary volume was estimated by dividing the daily urinary creatinine excretions by the observed values of concentration of creatinine in the urine, according to Valadares Filho \& Valadares (2001). Daily urinary creatinine excretion was estimated from the suggestion of $24.05 \mathrm{mg}$ creatinine per kg of live weight, for lactating cows (Chizzotti et al., 2007).
The balance of nitrogenous compounds was achieved by the difference between total nitrogen ingested and total nitrogen excreted in the feces, in the urine and in the milk. Analyses of allantoin in urine were performed through colorimetric method, according to the protocol described by Chen \& Gomes (1992). Analyses of creatinine, uric acid and urea in the urine were performed through commercial kit (Labtest Diagnóstica, Uréia CE, Lagoa Santa, Minas Gerais) via enzymatic colorimetric method. Total excretion of purine derivatives was calculated by the sum of amounts of allantoin and uric acid excreted in the diet and amount of allantoin excreted in the milk, expressed in mmol/day. The purines absorbed ( $\mathrm{X}, \mathrm{mmol} / \mathrm{day}$ ) were calculated from the excretion of purine derivatives $(\mathrm{Y}, \mathrm{mmol} / \mathrm{day})$, through the equation $\mathrm{Y}=0.85 \mathrm{X}+0.385 \mathrm{PV}^{0.75}$, where 0.85 is the recovery of purines absorbed as derivatives from purines and $0.385 \mathrm{PV}^{0.75}$, the endogenous contribution for the excretion of purines (Verbic et al., 1990).

The synthesis of microbial nitrogenous compounds in the rumen ( $Y, g$ N/day) was calculated in function of the purines absorbed ( $\mathrm{X}, \mathrm{mmol} / \mathrm{day})$, through the equation $\mathrm{Y}=(70 \mathrm{X}) /(0.83 \times 0.116 \times 1000)$, where 70 stands for the $\mathrm{N}$ content in the purines (mg N/mmol); 0.83 , the digestibility 
of microbial purines; and 0.116, the N-purine:total $\mathrm{N}$ in the bacteria ratio (Chen \& Gomes, 1992).

Cows were milked mechanically at $7 \mathrm{~h} 00$ and $14 \mathrm{~h} 00$, with daily recording of milk production. By means of dispenser attached to the milking machine, samples proportional to the milk production on the sixth day of the experimental period were made and conditioned in plastic bottles with bromopol ${ }^{\circledR}$, to be then sent to the Laboratório de análise da qualidade do leite (Laboratory of milk quality analysis) from Universidade Federal de Minas Gerais (UFMG), for evaluation of contents of fat, protein, lactose, total solids and defatted dry extract, following the technique described by the IDF (1995). Milk production corrected for $4.0 \%$ fat was calculated according to the NRC (2001).

Another part of the sample composed of milk was deproteinized with trichloroacetic acid $(10 \mathrm{~mL}$ milk mixed with $5 \mathrm{~mL} 25 \%$ trichloroacetic acid), filtered with quantitative filter paper and subsequently stored at $-20^{\circ} \mathrm{C}$ for urea and allantoin analyses. Analyses of allantoin in the whey were done through colorimetric method, according to Chen \& Gomes (1995). The urea in the whey was determined through commercial kit by the enzymatic colorimetric method (Labtest Diagnóstica, Uréia CE, Lagoa Santa, Minas Gerais, Brazil).

The statistical analyses for intake and digestibility of nutrients, milk composition and parameters of metabolic efficiency were performed through the model of multiple linear regression $Y=D_{0} \beta_{0}+\beta_{1} D_{1}+\beta_{2} D_{2}+\beta_{3} t+\beta_{4}\left(t * D_{1}\right)$ $+\beta_{5}\left(t^{*} D_{2}\right)+\beta_{6} t^{2}+\beta_{7}\left(t^{2 *} D_{1}\right)+\beta_{8}\left(t^{2 *} D_{2}\right)+\varepsilon$, where $D_{1}$ and $\mathrm{D}_{2}$ are dummy variables corresponding to the effects of genetic group, with $\mathrm{D}_{1}=0$ and $\mathrm{D}_{2}=0$ for Holstein $\times$ Nellore, $D_{1}=1$ and $D_{2}=0$ for Holstein $\times$ Guzerat, $D_{1}=0$ and $D_{2}=1$ for Holstein $\times$ Gir, and $t$ is the variable referring to the effect of time on intake and digestibility of nutrients, milk solids and parameters of metabolic efficiency. The critical level of $5 \%$ was adopted for type I error. The analysis was performed with the feature PROC REG of the statistical package SAS (Statistical Analysis System, version 9.2).

The Wood (1967) model was used for adjustment of lactation curves of cows from the three genetic groups, as follows: : $Y=a t^{b} e^{-c t}$; where $\mathrm{Y}=$ milk production (kg/day); $\mathrm{t}=$ week of lactation and $a ; b ; c=$ parameters to be estimated. Parameter $a$ stands for the initial value of milk production, parameter $b$ represents the value given to the intensity of the lactation peak, and parameter $c$ is the rate of drop in the daily production of milk after the peak. For the obtainment of the parameters of non-linear regression euqations, the iterative alghorythm of Marquardt and $t$ statistic were used for construction of the asymptotic confidence intervals for parameters $(1-\mathrm{a}=0.95)$, with the aid of the feature PROC NLIN of the software SAS version 9.2. For calculation of the standard deviation, the maximum likelihood estimation method was utilized.

The values of total milk production were estimated by means of the integral from 0 to 305 days of lactation applied to the functions utilized. Peak production was calculated through the highest value found at the moment the derivative of the fitted function equaled to zero.

\section{Results and Discussion}

There was no effect of genetic groups (Table 2) on the intakes of DM and the other nutrients $(\mathrm{P}<0.05)$. According to Reis et al. (2009), the variations in the response of the animal performance can be interpreted as a reflection of the forage quality, which is determined by two main factors, such as the DM intake and its nutritive value. However, in grazing systems, the DM intake is in function of the forage offer, considering that differences in the forage canopy may alter the ingestive behavior of grazing animals (Poppi et al., 1987).

According to Oldenbroek \& Jansen (1978), different breeds or genetic groups together, in grazing systems, present little difference in the pasture ingestion. The ingestive behavior is intrinsically bound to the nature of the food offered. In feedlot systems, for instance, the diet is supplied completely ready for consumption, with the possibility of identifying differences concerning genetic groups and other interactions. However, in grazing systems, the feed needs to be explored and collected by the animal, which makes the feeding a challenge, and other factors connected to the grazing characteristics become primordial at the determination of intake.

There was also no effect of genetic groups (Table 2 ) on the digestibility coefficients and the TDN contents $(\mathrm{P}<0.05)$. According to Forbes (1995), among the factors that directly affect the digestibility of a feedstuff, the intake level of the animal stands out as the most important. This relation obeys an inversely proportional pattern, i.e., the lower the intake level, the higher the digestibility of a feedstuff, an event that involves phenomena such as the reduction of the rumen passage rate (Merchen, 1988). As there was no effect of genetic groups for intake in the present study, it was expected that digestibility would follow this behavior, once the animals were subjected to the same diet.

According to Van Soest (1994), the digestibility of the $\mathrm{DM}$, and consequently, of the other nutrients, depends upon the content of cell wall and its availability for digestion, which is determined by the degree of lignification and other 
Table 2 - Means and coefficients of variation of the parameters obtained from F1 grazing cows of three genetic groups

\begin{tabular}{|c|c|c|c|c|}
\hline \multirow[b]{2}{*}{ Item $^{1}$} & \multicolumn{3}{|c|}{ Genetic groups ${ }^{1}$} & \multirow[b]{2}{*}{$\% \mathrm{CV}$} \\
\hline & HGI & $\mathrm{HGU}$ & HNE & \\
\hline \multicolumn{5}{|c|}{ Nutrient intake } \\
\hline DMI, kg & 12.53 & 12.23 & 12.00 & 15.1 \\
\hline DMI, \%BW & 2.39 & 2.18 & 2.19 & 20.3 \\
\hline OM, kg & 11.16 & 11.07 & 10.85 & 15.0 \\
\hline OM, \%BW & 2.16 & 1.97 & 1.98 & 20.2 \\
\hline $\mathrm{CP}, \mathrm{kg}$ & 1.58 & 1.53 & 1.48 & 24.2 \\
\hline NDFap, kg & 5.66 & 5.78 & 5.74 & 16.6 \\
\hline NDFap, \%BW & 1.10 & 1.03 & 1.05 & 22.3 \\
\hline $\mathrm{EE}, \mathrm{kg}$ & 0.28 & 0.28 & 0.27 & 13.5 \\
\hline NFCap, kg & 4.29 & 4.06 & 3.92 & 16.8 \\
\hline TDN, kg & 8.09 & 7.80 & 7.64 & 19.7 \\
\hline \multicolumn{5}{|c|}{ Digestibility } \\
\hline DM, \% & 61.82 & 60.63 & 60.72 & 8.8 \\
\hline СР, \% & 68.56 & 65.25 & 65.18 & 11.3 \\
\hline NDFap, \% & 54.57 & 54.07 & 56.09 & 16.2 \\
\hline EE, \% & 43.99 & 43.95 & 41.40 & 24.9 \\
\hline OM, \% & 64.00 & 63.12 & 62.88 & 8.8 \\
\hline NFCap, \% & 80.91 & 80.88 & 78.07 & 5.5 \\
\hline TDN, \% & 64.86 & 63.51 & 62.87 & 7.9 \\
\hline \multicolumn{5}{|c|}{ Milk composition } \\
\hline Fat, \% & 3.67 & 3.48 & 3.51 & 17.2 \\
\hline Protein, \% & 3.14 & 3.25 & 3.38 & 6.6 \\
\hline Lactose, \% & 4.73 & 4.74 & 4.65 & 3.3 \\
\hline Milk solids, \% & 12.35 & 12.36 & 12.48 & 5.9 \\
\hline Non-fat solids, \% & 8.71 & 8.89 & 8.97 & 3.0 \\
\hline \multicolumn{5}{|c|}{ Metabolic efficiency } \\
\hline NB, g/kg NI & 11.91 & 3.99 & 12.52 & 91.9 \\
\hline UUN, mg/day & 81.17 & 91.77 & 91.43 & 34.3 \\
\hline PUN, mg/dL & 11.62 & 10.90 & 10.14 & 25.3 \\
\hline MUN, mg/dL & 12.35 & 11.70 & 12.92 & 30.6 \\
\hline MN, g/day & 181.01 & 201.78 & 213.26 & 40.2 \\
\hline MPS, gCP/kgTDN & 153.76 & 167.28 & 163.38 & 40.8 \\
\hline
\end{tabular}

${ }^{1}$ HGI - Holstein $\times$ Gir; HGU - Holstein $\times$ guzerat; HNE - Holstein $\times$ Nellore;

2 DM - dry matter; OM - organic matter; CP - crude protein; NDFap - neutral detergent fiber corrected for ash and protein; EE - ether extract; NFCap - nonfiber carbohydrates corrected for ash and protein; TDN - total digestible nutrients; NB - nitrogen balance; NI - nitrogen intake; UUN - urine urea nitrogen; PUN - plasma urea nitrogen; MUN - milk urea nitrogen; MN microbial nitrogen; EF - microbial efficiency; CV - coefficient of variation.

factors. According to Prendiville et al. (2010), the digestibility of the diet for animals in grazing system is much affected by the variation in the rumination time and in the grazing behavior, which, in general, are not modified in function of genetic factors, but by body size. It is possible to detect the importance of the grazing behavior in the composition of the diet (Table 1), once there is an increase in the quality of the harvested forage when comparing the digestibility of nutrients at grazing and the forage collected by the animal (esophageal extrusa). As an example, one can observe the reduction in the contents of NDFap (from 67.15\% to 59.49\%); indigestible neutral detergent fiber - iNDF (from $35.34 \%$ to 22.81 ); and lignin (from $12.18 \%$ to $6.54 \%$ ) of the chosen forage in relation to the total forage available.
The nutrient intake presented variation over the lactation period $(\mathrm{P}<0.05)$ (Table 3$)$, showing quadratic behavior and positive critical point, with exception of the intake of DM and OM (\% body weight - BW), of NCF and TDN (kg and \%BW), which did not present effect of time $(\mathrm{P}>0.05)$. The maximum dry matter intake was estimated at $13.34 \mathrm{~kg}$ at 40 days of lactation; this fact seems to be closely connected to the characteristics of the pasture offered. The pasture presented lower NDF content in the extrusa around 42 days (Table 1 ), which coincides with the peak of intake of cows in this experiment.

The pasture presented, still in this stage, greater $\mathrm{CP}$ and NDF content and lower DM content, in spite of the lower pasture availability until 40 days of lactation (Table 1). According to Caird \& Holmes (2009), the maximum intake of dairy cows under grazing system does not coincide with the maximum pasture availability. The authors attribute such fact to the greater quality of the pasture chosen, which increases the density of nutrients of the diet. Such fact also explains the maximum CP intake at 44 days. Even though, one can perceive that the DM intake reported in the present study is considerably lower to those presented in studies with cows feeding on silages or chopped roughages.

The NRC (2001) reports intakes of up to $25 \mathrm{~kg}$ dry matter per cow/day. However, cows feeding on pastures present a series of restrictions to intake - previously discussed in this study - added to the fact that tropical grasses present nutritional quality inferior to those of temperate climate, which are characteristics intrinsic to the physiology of C4 plants. These grasses present higher content of lignin in the cell wall and, consequently, iNDF content, in addition to the low-digestibility tissues like the xylem and the sclerenchyma (Paciullo, 2002).

According to the NRC (2001), in addition to the nutrition factors, inherent to the diet, metabolic factors contribute to significant increases in the intake at the beginning of lactation. The DM intake increases rapidly at postpartum, causing an increase in the gastrointestinal tract length, about $4 \mathrm{~kg}$ in its capacity, per kg of increase in intake. After the DM intake peak, which, in the case of the present study, occurred at 40 days (5 weeks), intake decreases and the gastrointestinal tract regresses to make way to pregnancy.

For NDFap intake, the peak occurred at 50 days (Table 3), and for NDFap (\%BW), the peak occurred beforehand, at 36.6 days. This may have been in function of the mobilization of the body reserves of the cow and the weight loss which typically occurs at the beginning of the lactation period, which increase the relevance of the NDFap intake value in the ratio with body weight, which showed reduction. The NDFap intake followed DM intake associated to the 
Table 3 - Estimated parameters in multiple linear regressions and critical points of the significant variables $(\mathrm{P}<0.05)$ as a function of the days in milking, for F1 grazing cows

\begin{tabular}{|c|c|c|c|c|c|c|c|c|}
\hline \multirow[t]{2}{*}{ Item } & \multicolumn{3}{|c|}{ Regression parameters } & \multirow[b]{2}{*}{ R-SD } & \multirow[b]{2}{*}{$\mathrm{R}^{2}$} & \multirow[b]{2}{*}{ P-value } & \multicolumn{2}{|c|}{ Critical point } \\
\hline & Intercept & $\mathrm{t}$ & $t^{2}$ & & & & $\begin{array}{l}\text { Position (days) } \\
\text { response }\end{array}$ & Expected \\
\hline CPI, kg & 1.6181 & 0.0035 & -.0000392 & 0.37 & 0.1985 & $<0.0001$ & 44.64 & 1.70 \\
\hline NDFapI, kg & 5.9112 & 0.0161 & -0.000161 & 0.95 & 0.3494 & $<0.0001$ & 50.00 & 6.31 \\
\hline NDFapI, \%BW & 1.1496 & 0.0016 & -0.000022 & 0.23 & 0.2157 & $<0.0001$ & 36.36 & 1.18 \\
\hline CPd, \% & 85.896 & -0.2710 & 0.000543 & 7.94 & 0.4553 & $<0.0001$ & 249.53 & 52.08 \\
\hline $\mathrm{dNDF}_{\mathrm{ap}} \%$ & 65.750 & 0.0183 & -0.000878 & 9.28 & 0.4314 & $<0.0001$ & 10.42 & 65.84 \\
\hline TDN, \% & 72.0420 & -0.09228 & - & 5.04 & 0.3525 & $<0.0001$ & - & - \\
\hline Milk protein, \% & 3.478 & -0.00717 & 0.000042 & 0.21 & 0.1529 & 0.0003 & 85.35 & 3.17 \\
\hline Non-fat solids, \% & 9.131 & -0.0074 & 0.000039 & 0.27 & 0.0769 & 0.0214 & 94.87 & 8.78 \\
\hline $\mathrm{UUN}, \mathrm{mg} / \mathrm{d}$ & 93.426 & 0.39019 & -0.00397 & 30.64 & 0.2317 & $<0.0001$ & 49.14 & 103.01 \\
\hline
\end{tabular}

DMI - dry matter intake; OMI - organic matter intake; CPI - crude protein intake; NDFapI - neutral detergent fiber corrected for ash and protein intake; EEI - ether extract intake; CPd - crude protein digestibility; dNDFap - digestibility of neutral detergent fiber corrected for ash and protein; TDN - total digestible nutrient; UUN - urine urea nitrogen; PUN - plasma urea nitrogen; MUN - milk urea nitrogen; BW - body weight.

significant increase in the NDFap content of the pasture (Table 1) in the period corresponding to the interval of 42 and 63 lactation days. Kolver \& Muller (1998) showed that rises in the NDF intake occur from the moment the availability of pasture increases, and, in the present study, although the peak of DM intake occurred at 40.26 days, the forage availability in the interval of 42 to 63 days increased considerably (from 4.50 to $6.45 \mathrm{t} / \mathrm{ha}$ ), which is a primordial factor for increasing NDFap intake and resulting in the peak of the intake of such nutrient at 50 days.

The ether extract (EE) intake presented behavior similar (Table 3) to the other nutrients, showing peak of intake at 52.22 days $(\mathrm{P}<0.05)$. Since the $\mathrm{EE}$ content in the forage was little, one can infer that the intake of this nutrient is in function of the intake of DM of pasture plus DM of concentrate; just like in the case of the organic matter, with intake peak at 38.48 days $(\mathrm{P}<0.05)$, which is very similar to the $\mathrm{DM}$, once both nutrients are very correlated to themselves.

The coefficients of digestibility of CP, of NDFap and the content of TDN (Table 3) were the only affected by the lactation period $(\mathrm{P}<0.05)$. The digestibility coefficients of DM, OM, EE and NFC, on the other hand, did not vary over time $(\mathrm{P}>0.05)$. Digestibility coefficients of DM and OM did not present this effect, possibly because the DM digestibility is usually affected by nutritional factors or by the nutritional value of the diet. Thus, with reduction in the nutritional value of the pasture, there was reduction in DM intake and greater animal selectivity, with no harm to the digestibility of DM and OM over time.

Crude protein showed minimum digestibility estimate at 249.53 days. In general, with the lignifications process, the proportion of proteins associated with the cell wall increases, playing important role on the chemical bonds with some polysaccharides (Van Soest, 1994), becoming insoluble. This nitrogen bound to the cell wall is relatively indigestible and little utilized, and it is possible to observe such effect through the values in the last experimental periods, with $79 \%$ of the total nitrogen in the form of neutral detergent insoluble nitrogen (NDIN). In the extrusa, this value drops to $55 \%$ due to the selectivity of animals (Table 1). Thus, throughout the lactation, the process of physical maturation of the grasses affected the $\mathrm{CP}$ digestibility.

The digestibility coefficient of the NDFap reaches its maximum at 10.42 days of lactation, and TDN contents presented linear reduction, not showing the quadratic parameter of the regression. Both results can also be attributed to the constant decrease in the nutritive value of the pasture.

From the model of Wood (1967), three equations were obtained for estimation of the production of Holstein $\times$ Gir cows $=17.2667 * \mathrm{t}^{0.0652} \mathrm{e}^{-0.00424 \mathrm{t}}$, Holstein $\times$ Guzerat $=$ $18.1470 * \mathrm{t}^{0.0332} \mathrm{e}^{-0.00408 * \mathrm{t}}$ and Holstein $\times$ Nellore $=$ $14.2836 * \mathrm{t}^{0.1059} \mathrm{e}^{-0.00552 \mathrm{t}}$ (Table 4 ), generating, thus, distinct lactation curves for these genetic groups (Figure 1). Holstein $\times$ Gir cows presented lactation peak of $19.33 \mathrm{~kg} /$ day at 15 days, and Holstein $\times$ Guzerat cows presented peak of $19.08 \mathrm{~kg} /$ day at 8 days. According Keown et al. (1986) there is a trend to delay in the lactation period for cows with higher production level. Despite the little difference in the number of days, Holstein $\times$ Gir cows presented longer time $(P<0.05)$ for reaching the peak. These two crossings also have their 
production coinciding at the end of lactation, when the stabilization of milk production in the lowest level of production occurs. However, it is possible to state that the persistence in the lactation of Holstein $\times$ Guzerat cows is inferior $(\mathrm{P}<0.05)$ to Holstein $\times$ Gir animals. The milk production kept by Holstein $\times$ Gir cows at the end of lactation, at 305 days, in relation to the peak, was $35.58 \%$ $(6.87 \mathrm{~kg} /$ day), a value slightly superior to that of Holstein $\times$ Guzerat cows, which was $33.60 \%$ (6.41 kg/day), with total production projected at 305 days of lactation of Holstein $\times$ Gir cows (3938 kg) superior in relation to Holstein $\times$ Guzerat cows ( $3713 \mathrm{~kg}$ ), probably in function of their lower production drop rate.

Genetic group Holstein $\times$ Nellore presented lower accumulated milk production than the other groups (Figure 1), with $3335 \mathrm{~kg}$ at 305 days, with mild lactation peak at 19 days. Its maximum lactation was $17.56 \mathrm{~kg} /$ day, with lower persistence at lactation, keeping only $27.68 \%$ of the peak production at 305 days of lactation, and the initial production for this group was also lower, according to the data observed when comparing the intercepts of the equations (Table 1 ). Holstein $\times$ Nellore cows, for presenting lower persistence at lactation showed greater proportion of lactation within their pasture station. This detail can be better viewed when the parameters of the lactation curves are analyzed. The parameter $c$ of the cows of this group was the greatest among the others $(\mathrm{P}<0.05)$, which indicates higher rate of drop in production. Parameter $b$ was also superior, which indicates a lactation peak more marked than the other groups; besides, they also present the lowest parameter $a$, which indicates lower initial production on the first lactation days.

There was no effect $(\mathrm{P}>0.05)$ of genetic group on the content of milk solids (Table 2). According to Palmquist et al. (1993), the main sources of variation that may alter milk

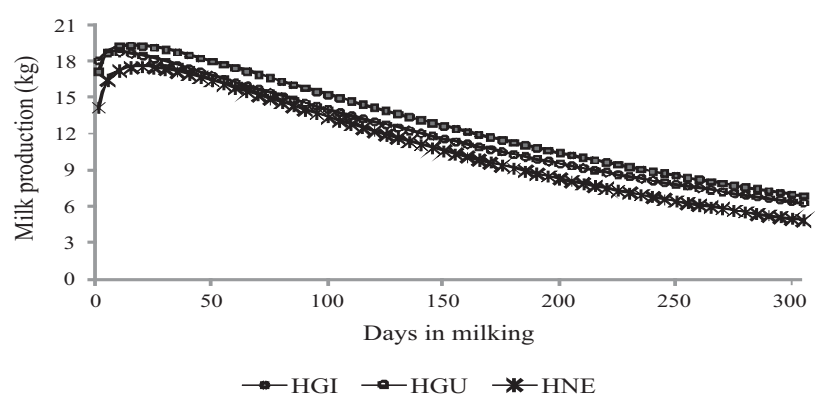

Figure 1 - Lactation curves of the F1 Holstein $\times$ zebu cows of different genetic groups, as follows: HGI - Holstein $\times$ Gir: $\mathrm{Y}=17.2667 * \mathrm{t}^{0.0652} * \mathrm{e}^{-0.00424 t} ; \mathrm{HGU}-$ Holstein

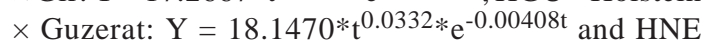
- Holstein $\times$ Nellore: $\mathrm{Y}=14.2836 * \mathrm{t}^{0.1059 * \mathrm{e}^{-0.00552 \mathrm{t}}}$ composition are lactation phase, which considerably alters the physiological status of the cow, and season of the year, which acts on the modification of the origin and type of feedstuffs. According to Weigel et al. (1999), there is low heritability for production of fat in the milk of cows under pasture production systems, when compared with cows kept in feedlot, which makes it clear that the genetic characteristics are not important factors at the alteration of solids in the milk. Kearney et al. (2004) affirm that genes for the production of milk and protein in the milk present different expression in herds considered of low production, with reduction in the genetic correlation between milk production and protein in the milk, when environmental characteristics become more varied, as in the case of the grazing environment.

The variable time did not affect $(\mathrm{P}>0.05)$ contents of fat in the milk, total solids and lactose (Table 3). From the milk component, fat content is the one which presents greater variation in function of feeding. Overall, alterations in the fat content may inform about the rumen fermentation process. Bauman \& Griinari (2000) presented a series of theories to explain these alterations, all of them based on modifications in the rumen fermentation pattern. Thus, it is possible to infer that the differences in the nutritive value of the forage throughout lactation did not reflect in alterations in the rumen fermentation profile throughout lactation, so it was not possible to modify the fat content in the milk.

Lactose, in turn, is the component which presents the smallest variation among all the components here assessed, and, in general, represents constant percentage in the milk, with its amount varying according to the volume. Therefore, it was already expected that the percentage of lactose in the milk would not present variation over time of lactation or genetic group.

Contrastingly, the milk protein was altered in function of time $(\mathrm{P}<0.05)$, presenting quadratic behavior and minimum percentage in the milk of $3.17 \%$ at 85.35 days (Table 3 ). This decrease in the percentage of protein from the beginning of lactation is probably associated to the behavior in the TDN content, which presented decreasing linear behavior, and to the contents of NFC in the extrusa (Table 1), which decreased until 85 days. According to the NRC (2001), the percentage of protein in milk is not significantly affected by the CP content in the diet, and is poorly correlated with the amount of protein in the milk $(r=0.14)$. For there to be any alteration or increase in the milk protein, more NFC supplement would be necessary, which would result in increase of the microbial protein produced, and also of the amount of amino acids that reach the mammary gland for the synthesis of protein. Only an elevated intake of 
NFC that supplied more quantity of propionate could cause reduction in the catabolism of amino acids, with a consequent increase in the content of amino acids free for the protein formation. In the case of the present experiment, at about 85.35 days of experiment - estimated date of the point of minimum percentage of protein in the milk - the lowest NFC percentage in the extrusa was found (Table 1).

The defatted dry extract (DDE), in its majority, is composed of the milk protein and lactose. Thus, the DDE followed the behavior presented by protein, once lactose remained unchanged in function of time, the DDE (Table 3 ) also presented minimum estimated value $(\mathrm{P}<0.05)$ of $8.78 \%$ (Table 4) at 94.87 days of lactation $(\mathrm{P}<0.05)$.

There was no effect of genetic group $(\mathrm{P}>0.05)$ for the characteristics associated to the nitrogen use efficiency (Table 2). The nitrogen balance, the excretion of urea in the urine, the urea nitrogen in the milk and in the plasma act as biochemical indicators of the status of the animal. According to Hammond (1997), the values of urea nitrogen in the milk and in the plasma can be utilized as indicators of biological response of ruminants to supplementation with energy and protein and to changes relative to the type of forage offered, which leads us to conclude that, in this case, the nutritional factors are more marked than the genetic factors. The excretion of urea in the urine also did not present variation in function of genetic groups $(\mathrm{P}>0.05)$, following the trend of most indicators of the protein status. Kauffman \& St-Pierre (2001) evaluated differences in the protein metabolism of Jersey and Holstein cows and verified significant difference between the breeds for parameters like milk production and its components. However, no variations were verified for urea nitrogen in the plasma or urea nitrogen in the milk between groups.

Microbial nitrogen and microbial efficiency also present the role of metabolic indicators. However, they are more specific for the evaluation of the rumen microbial metabolism. In general, the microbial growth or the protein synthesis is in function of the energy availability (Hoover \& Stokes, 1991). From the factors that affect the microbial protein synthesis, availability and synchronization of energy and nitrogen compounds in the rumen have been recognized as the most important (Russel et al., 1992). In this study, none of these factors presented variation as for genetics, and they were inherent to the alterations resulting from the nutritional and metabolic statuses of the animals.

Microbial nitrogen production and microbial efficiency also did not present variation in function of lactation duration ( $P>0.05)$. This might have been in function of the low mean content (Table 1) of nitrogen in the pasture (5.11\%), which becomes limiting even with some variations in the supply of carbohydrates (Table 1), once the microbial efficiency is directly linked to the synchronization of protein and energy of the diet. Even in the time range in which nitrogen was at its maximum (8.18\%), during the $21^{\text {st }}$ and $32^{\text {nd }}$ days of lactation (Table 1), the TDN intake and CP digestibility also showed in decrease in function of time, which can yet reveal a situation of energetic imbalance in some stages of lactation, which is a limiting factor for microbial production.

The excretion of urea in the urine presented quadratic behavior in function of lactation days $(\mathrm{P}<0.05)$, with maximum estimated excretion of $103.01 \mathrm{mg} / \mathrm{kg} \mathrm{BW}$ at 49.14 days (Table 4). Although nitrogen showed limiting in the pasture, overall, analyzing the first weeks of lactation, once can perceive that these nitrogen losses in the urine are likely to have occurred in function of an imbalance between protein and milk of the diet, for this was the period when the pasture showed highest CP content and cows showed maximum intake of this nutrient at 44.64 days (sixth week). According to Wright et al. (1998), when cows present increase in excretion of nitrogen in the urine, in this case, in the form of urea, this may indicate insufficiency of energy substrate available in the rumen for productive use of nitrogen.

The urea nitrogen in the milk and the urea nitrogen in the plasma, in turn, presented quadratic behavior $(\mathrm{P}<0.05)$, with minimum concentrations estimated at 121.53 and 119.09 days, respectively (Table 4). This verifies, once more, that, in spite of the occurrence of peak of urea excretion in the urine during the sixth week of lactation, overall, nitrogen showed as a limiting nutrient, during the other weeks of lactation. Broderick \& Clayton (1997) reported that

Table 4 - Estimated parameters for the Wood (1967) model used to fit lactation curves of F1 grazing cows

\begin{tabular}{|c|c|c|c|}
\hline \multirow[t]{2}{*}{ Parameters } & \multicolumn{3}{|c|}{ Genetic group } \\
\hline & Holstein $\times$ Gir & Holstein $\times$ Guzerat & Holstein $\times$ Nellore \\
\hline $\mathrm{a}$ & $17.2667 \pm 2.5145$ & $18.1470 \pm 1.2313$ & $14.2836 \pm 2.0699$ \\
\hline b & $0.0652 \pm 0.0421$ & $0.0332 \pm 0.0209$ & $0.1059 \pm 0.0444$ \\
\hline c & $0.00424 \pm 0.00045$ & $0.00408 \pm 0.00028$ & $0.00552 \pm 0.00057$ \\
\hline ASD & 2.07 & 1.89 & 2.52 \\
\hline
\end{tabular}

Wood (1967): $\mathrm{Y}=\mathrm{at}^{\mathrm{b}} \mathrm{e}^{-\mathrm{ct}} ;$ ASD - assintotic standard deviation. 
concentration of urea nitrogen in the milk below $14 \mathrm{mg} \mathrm{N} / \mathrm{dL}$ indicates deficiency of CP per unit of dietary energy, which sets the status of imbalance between protein and energy. In this study, this may have occurred in this phase of lactation in function of the rapid drop in the CP of the pasture (Table 1 ), once at 121.53 days, the urea nitrogen in the milk reached minimum estimated concentration of $11.21 \mathrm{mg} / \mathrm{dL}$ (Table 4).

\section{Conclusions}

The utilization of genetic groups of Holstein $\times$ Zebu grazing cows does not cause alteration on intake or nutrient digestibility, nor on nitrogen compounds use efficiency. Nevertheless, such variables suffer alteration in function of lactation period, presenting, in general, quadratic behavior for the three genetic groups studied. F1 Holstein $\times$ Gir cows present higher accumulated production during lactation and more persistence, followed by F1 Holstein $\times$ Guzerat cows. The group of F1 Holstein $\times$ Nellore animals presents lower accumulated milk production and lower persistence at lactation.

\section{References}

ASSOCIATION OF OFFICIAL ANALYTICAL CHEMISTRY AOAC. 1990. Official methods of analysis. 15.ed. Washington: AOAC Internationl, 1990. 1025p.

BAUMAN, D.E.; GRIINARI, J.M. Regulation and nutritional manipulation of milk fat: Low-fat milk syndrome. Livestock Production Science, v.70, p.15-29, 2000.

BRODERICK, G.A.; CLAYTON, M.K. A statistical evaluation of animal and nutritional factors influencing concentrations of milk urea nitrogen1. Journal of Dairy Science, v.80, p.2964-2971, 1997.

CAIRD, L.; HOLMES, W. The prediction of voluntary intake of grazing dairy cows. The Journal of Agricultural Science, v.107, p.43-54, 2009

CASALI, A.; DETMANN, E.; VALADARES FILHO, S.C. Influência do tempo de incubação e do tamanho de partículas sobre os teores de compostos indigestíveis em alimentos e fezes bovinas obtidos por procedimentos in situ. Revista Brasileira de Zootecnia, v.37, p.335-342, 2008.

CHEN, X.B.; GOMES, M.J. Estimation of microbial protein supply to sheep and cattle based on urinary excretion of purine derivatives-an overview of the technical details. Buchsburnd Aberdeen: Rowett Research Institute, 1992. 21p.

CHIZZOTTI, M.L.; VALADARES FILHO, S.C.; VALADARES, R.F.D. et al. Intake, digestibility and nitrogen metabolism in holstein cows with different milk production levels. Revista Brasileira de Zootecnia, v.36, p.138-146, 2007.

DETMANN, E.; VALADARES FILHO, S.C. On the estimation of nonfibrous carbohydrates in feeds and diets. Arquivo Brasileiro de Medicina Veterinária e Zootecnia, v.62, p.980-984, 2010.

FORBES, J.M. Voluntary food intake and diet selection in farm animals. Wallingford: $\mathrm{CAB}, 1995$. 532p.

HAMMOND, A.C. Update on BUN and MUN as a guide for protein supplementation in cattle. In: ANNUAL FLORIDA RUMINANT
NUTRITION SYMPOSIUM, 8., 1997, Cainesville. Anais... Gainesville: University of Florida, 1997. p.45.

HOOVER, W.H.; STOKES, S.R. Balancing carbohydrates and proteins for optimum rumen microbial yield. Journal of Dairy Science, v.74, p.3630-3641, 1991.

INTERNATIONAL DAIRY FEDERATION - IDF. Milk and milk products: methods of sampling. Brussels, 1995. p.25. (IDF Standard, $50 \mathrm{C}$ ).

KAUFFMAN, A.J.; ST-PIERRE, N.R. The relationship of milk urea nitrogen to urine nitrogen excretion in holstein and Jersey cows. Journal of Dairy Science, v.84, p.2284-2294, 2001.

KEARNEY, J.F.; SCHUTZ, M.M.; BOETTCHER, P.J. et al. Genotype $\mathrm{x}$ environment interaction for grazing versus confinement. I. Production traits. Journal of Dairy Science, v.87, p.501-509, 2004.

KEOWN, J.F.; EVERETT R, W.; EMPET, N.B. et al. Lactation curves. Journal of Dairy Dcience, v.69, p.769-781, 1986.

KOLVER, E.S.; MULLER, L.D. Performance and nutrient intake of high producing holstein cows consuming pasture or a total mixed ration1. Journal of Dairy Science, v.81, p.1403-1411, 1998.

LICITRA, G.; HERNANDEZ, T.M.; VAN SOEST, P.J. Standardization of procedures for nitrogen fractionation of ruminant feeds. Animal Feed Science and Technology, v.57, p.347-358, 1996.

MCMENIMAM, N.P. Methods of estimating intake of grazing animals. In: REUNIÃO ANUAL DA SOCIEDADE BRASILEIRA DE ZOOTECNIA, 34., 1997, Juiz de Fora. Anais... Juiz de Fora: Sociedade Brasileira de Zootecnia, 1997. p.131-168.

MERCHEN, N.R. Digestion, absorption and excretion in ruminants. In: CHURCH, D.C.(Ed.) The ruminant animal: digestive physiology and metabolism. New Jersey: Prentice Hall, 1988. p.172-201.

MERTENS, D. R. Gravimetric determination of amylase-treated neutral detergent fiber in feeds with refluxing in beakers or crucibles: Collaborative study. Journal of AOAC Institute, v.85, p.1217-1240, 2002.

MYERS, W.D.; LUDDEN, P.A.; NAYIGIHUGU, V. et al. Technical note: A procedure for the preparation and quantitative analysis of samples for titanium dioxide. Journal of Animal Science, v.82, p.179-183, 2004.

NATIONAL RESEARCH COUNCIL - NRC. Nutrient requirements of dairy cattle. 7.ed. Washington, D.C.: National Academy, 2001. 381p.

OLDENBROEK, J.K.; JANSEN, A.A.M. The effect of the grazing behaviour of a breed on the performance of another breed, when they are grazing together. Zeitschrift für Tierzüchtung und Züchtungsbiologie, v.95, p.132-139, 1978.

PALMQUIST, D.L.; BEAULIEU, A.D.; BARBANO, D.M. Feed and animal factors influencing milk fat composition. Journal of Dairy Science, v.76, p.1753-1771, 1993.

POPPI, D.P.; HUGHES, T.P.; L'HUILLIER, P.J. Intake of pasture by grazing ruminants. In: NICOL, A.M. (Ed.) Feeding livestock on pasture. Hamilton: New Zeland Society of Animal Production, 1987. p.55-63. (Occasional Publication, 10)

PRENDIVILLE, R.; PIERCE, K.M.; BUCKLEY, F. A comparison between holstein-friesian and jersey dairy cows and their f1 cross with regard to milk yield, somatic cell score, mastitis, and milking characteristics under grazing conditions. Journal of Dairy Science, v.93, p.2741-2750, 2010.

REIS, R.A.; RUGGIERI, A.C.; CASAGRANDE, D.R. et al. Suplementação da dieta de bovinos de corte como estratégia do manejo das pastagens. Revista Brasileira de Zootecnia, v.51, p.147-159, 2009.

RUSSELL, J.B.; O’CONNOR, J.D.; FOX, D.G. A net carbohydrate and protein system for evaluating cattle diets: I. Ruminal fermentation. Journal of Animal Science, v.70, p.3551-3561, 1992.

VALADARES FILHO, S.C.; VALADARES, R.F.D. Recentes avanços em proteína na nutrição de vacas leiteiras. In: SIMPÓSIO 
INTERNACIONAL DE BOVINOCULTURA LEITEIRA, SIMLEITE, 2., 2001, Lavras. Anais... Lavras: Universidade Federal de Lavras, 2001. p.228-243.

VALADARES, R.F.D.; GONÇALVES, L.C.; RODRIGUEZ, N.M. Níveis de proteína em dietas de bovinos. 4. Concentrações de amônia ruminal e uréia plasmática e excreções de uréia e creatinina. Revista Brasileira de Zootecnia, v.26, p.1270-1278, 1997.

VAN SOEST, P.J.; WINE, R. Use of detergents in the analysis of fibrous feeds, Iv. Determination of plant cell-wall constituents. Journal of AOAC Institute, v.50, p.50-55, 1967.

VAN SOEST, P.J. Nutritional ecology of the ruminant. 2.ed. Ithaca: Cornell University Press, 1994. 476p.

VERBIC, J.; CHEN, X.B.; MACLEOD, N.A. Excretion of purine derivatives by ruminants. Effect of microbial nucleic acid infusion on purine derivative excretion by steers. The Journal of Agricultural Science, v.114, p.243-248, 1990.

WEIGEL, K.A.; KRIEGL, T.; POHLMAN, A.L. Genetic analysis of dairy cattle production traits in a management intensive rotational grazing environment. Journal of Dairy Science, v.82, p.191-195, 1999.

WEISS, W.P. Energy prediction equations for ruminant feeds. In: CORNELL NUTRITION CONFERENCE FOR FEED MANUFACTURERS, 61. 1999, Ithaca. Anais... Ithaca: Cornell University, 1999. p.176-181. WOOD, P.D.P. Algebraic model of the lactation curve in cattle. Nature, v.216, p.164-165, 1967.

WRIGHT, T.C; MOSCARDINI, S.; LUIMES, P.H. et al. Effects of rumen-undegradable protein and feed intake on nitrogen balance and milk protein production in dairy cows. Journal of Dairy Science, v.81, p.784-793, 1998. 